\title{
Influence of Calcination Temperature on Size, Morphology and Optical Properties of ZNO/C Composite Synthesized by a Colloidal Method
}

\author{
Siham Lhimr ${ }^{*}$, Saidati Bouhlassa, and Bouchaib Ammary \\ Department of Chemistry, University of Mohammed V Agdal, Rabat, Morocco
}

*Corresponding author:

tel: $+212-676463299$

email: siham.lhimr@gmail.com

Received: December 19, 2020

Accepted: March 31, 2021

DOI: $10.22146 /$ ijc.56309

\begin{abstract}
ZnO}$ is one of the most studied semiconductor materials because of its interesting chemicals, and from a technological point of view, mainly as a consequence of their outstanding properties, such as wurtzite type, non-toxic nature, large band gap, low cost, and environment-friendly. In this work, the $\mathrm{ZnO} / \mathrm{C}$ composite was synthesized by a simple and fast low-temperature method; the solid product was calcination temperature at 100 to $400{ }^{\circ} \mathrm{C}$. The influence of variation in calcination temperature was studied using $X$-ray diffraction (XRD), Fourier transforms infrared spectroscopy (FTIR), scanning electron microscopy (SEM), and UV-visible diffuse reflectance spectroscopy. The X-ray diffraction patterns indicated a high crystallinity and a nanocrystalline size of the $\mathrm{ZnO} / \mathrm{C}$ composite hexagonal structure of wurtzite. The SEM image of the samples showed that the powder has a spherical structure of flakes aggregated in the common nucleus like a grid. The sphere consists of spindle and flower-like structures. The optical properties were determined by UV-vis diffuse reflectance spectroscopy, and it was found that the band gap energy of $\mathrm{ZnO} / \mathrm{C}$ composite increase from 3.210 to $3.329 \mathrm{eV}$ with an increase in calcination temperature from 100 to $400{ }^{\circ} \mathrm{C}$. FTIR spectra and EDS analysis showed that the existence of carbon in the composite.
\end{abstract}

Keywords: $\mathrm{ZnO} / \mathrm{C}$ composite; calcination temperature; colloidal method; morphology; optical properties

\section{- INTRODUCTION}

Materials based on zinc oxide are the most interesting from a technological point of view, mainly because of their remarkable properties, such as the wide direct band gap of around $3.37 \mathrm{eV}$, a semiconductor material with a high exciton binding energy of $60 \mathrm{meV}$ at room temperature [1], crystallizes in the typical hexagonal wurtzite structure with lattice parameters $\mathrm{a}=\mathrm{b}$ $=0.325 \mathrm{~nm}$ and $\mathrm{c}=0.521 \mathrm{~nm}$ [2]. All these properties make them widely applied in several fields, such as lightemitting diodes [3], solar cells [4], photocatalysis [5], and photovoltaic applications [6].

Carbon as a good candidate is used as a host material for composite because of its properties, such as high surface area and conductivity. The combination of $\mathrm{ZnO}$ with carbon will result in an intermediate energy level in the band gap of the material and reduce its absorption energy. Previous studies on $\mathrm{ZnO} /$ carbon composites have improved the structural, morphological, vibrational properties and reduce the band gap of broadband semiconductors of $\mathrm{ZnO}$ [7]. Osman et al. [8] reported the synthesis of $\mathrm{ZnO} / \mathrm{C}$ nanocomposite using glucose and observed enhanced visible-light photocatalytic activity. On the other hand, Jayalakshmi et al. [9] described the synthesis of $\mathrm{ZnO} / \mathrm{C}$ Nanocomposite by the thermal decomposition using dextrose for the application of supercapacitors. There are different synthesis methods used to produce a $\mathrm{ZnO} / \mathrm{C}$ composite, such as the sol-gel method [10], a hydrothermal method [11], microemulsion method [12], thermal decomposition [13], combustion method [14], and microwave-assisted method [15]. The Thermal treatment, for example, calcinations, would remove impurities, and the second chemical phase, used as a capping agent, would give a pure product. In addition, calcinations effectively modify the crystalline phase to obtain a homogeneous one. 
Therefore, the combination of the two methods, chemical and thermal, makes it possible to produce nanoparticles of better size and better crystalline phase [16-17]. In this work, we report synthesized the $\mathrm{ZnO} / \mathrm{C}$ composite using the colloidal method. It is a simple and inexpensive method and does not take much time to prepare the nanoparticles, and citric acid is used as a source of carbon. The aim of this research is The $\mathrm{ZnO} / \mathrm{C}$ composite was then calcined at different temperatures 100,300, and $400{ }^{\circ} \mathrm{C}$ to study the influence of heat treatment on the morphology and size of the $\mathrm{ZnO} / \mathrm{C}$ composite. The structural properties, the particle size, the morphological and optical properties of the synthesized $\mathrm{ZnO} / \mathrm{C}$ composite were characterized by Fourier Transform Infrared spectroscopy (FTIR), X-ray diffraction spectroscopy (XRD), scanning electron microscope (SEM), and UV-visible diffuse reflectance spectroscopy.

\section{- EXPERIMENTAL SECTION}

\section{Materials}

Materials used were Zinc nitrate hexahydrate $\left(\mathrm{Zn}\left(\mathrm{NO}_{3}\right)_{2} \cdot 6 \mathrm{H}_{2} \mathrm{O}\right.$, Panreac, Espagne), citric acid monohydrate $\left(\mathrm{C}_{6} \mathrm{H}_{8} \mathrm{O}_{7} . \mathrm{H}_{2} \mathrm{O}\right.$, Panreac, Espagne), and sodium hydroxide $(\mathrm{NaOH}$, Prolabo, Suisse).

\section{Instrumentation}

The structure and particle size were characterized by X-ray diffraction (XRD) with $\mathrm{CuK}(\lambda=0.1546 \mathrm{~nm})$. The existence of carbon indicated by the infrared absorption spectra was recorded over a range of 4000 to $400 \mathrm{~cm}^{-1}$ on an infrared spectrophotometer with Fourier transform. The morphology and the particle size of the product obtained were analyzed by scanning electron microscopy. The optical property was analyzed by UV-visible diffuse reflectance spectroscopy.

\section{Procedure}

The used procedure was prepared by our previously reported method but modified by calcined at different temperatures for $\mathrm{ZnO} / \mathrm{C}$ composite [18]. $\mathrm{ZnO} / \mathrm{C}$ composite was prepared using the colloidal method. First, the Zinc nitrate hexahydrate $\left(\mathrm{Zn}\left(\mathrm{NO}_{3}\right)_{2} \cdot 6 \mathrm{H}_{2} \mathrm{O} ; 0.954 \mathrm{~g}\right)$ and citric acid monohydrate $\left(\mathrm{C}_{6} \mathrm{H}_{8} \mathrm{O}_{7} \cdot \mathrm{H}_{2} \mathrm{O} ; 2.101 \mathrm{~g}\right)$ were fully dissolved in distilled water $(10 \mathrm{~mL})$ and stirring at room temperature for $30 \mathrm{~min}$, Zinc Nitrate Hexahydrate to obtain $0.7 \mathrm{M}$ and $1 \mathrm{M}$ of citric acid.

Secondly, $1.4 \mathrm{M} \mathrm{NaOH}$ was directly and rapidly dropped into the first aqueous solutions with a molar ratio $\left(\mathrm{r}=\mathrm{n}_{\mathrm{OH}} / \mathrm{n}_{\mathrm{Zn} 2+}=6: 1\right)$ at room temperature. Then the white colloidal was recovered by centrifugation and washed several times with distilled water. Then, the resulting products were placed in an oven at a temperature of $40{ }^{\circ} \mathrm{C}$ for 3 days. Finally, the powder obtained by the above process was thermal treatment at a different temperature such as 100,300 , and $400{ }^{\circ} \mathrm{C}$ in the air for $1 \mathrm{~h}$.

\section{Different relations used for measurement of properties}

The average size D can be calculated DebyeScherrer formula [19]:

$\mathrm{D}=\frac{\mathrm{k} \lambda}{\mathrm{B} \cos \theta}$

were $D$ is average crystallite size, $\lambda$ the wavelength of CuKal taken as $0.1546 \mathrm{~nm}, \theta$ is the diffraction angle, and $B$ the width of the peaks (FWHM) in radians.

The lattice parameters ( $a$ and $c$ ) have been determined by using the following formula [20]:

$\frac{1}{\mathrm{~d}^{2}}=\frac{4}{3}\left(\frac{\mathrm{h}^{2}+\mathrm{hk}+\mathrm{k}^{2}}{\mathrm{a}^{2}}\right)+\frac{\mathrm{l}^{2}}{\mathrm{c}}$

Referring to Bragg law, it is possible to rewrite Eq. (2) as follows:

$\frac{4 \sin ^{2} \theta}{\lambda^{2}}=\frac{4}{3}\left(\frac{\mathrm{h}^{2}+\mathrm{hk}+\mathrm{k}^{2}}{\mathrm{a}^{2}}\right)+\frac{\mathrm{l}^{2}}{\mathrm{c}}$

The lattice constant ' $a$ ' is derived for the plane (100) by the relation (4):

$\mathrm{a}=\frac{\lambda}{\sqrt{3 *} \sin \theta}$

The lattice parameter $\mathrm{C}$ is calculated for the (002) plane using the following Eq. (5):

$c=\frac{\lambda}{\sin \theta}$

where $d$ is lattice spacing, a and $c$ are lattice constants; $h$, $\mathrm{k}, \mathrm{l}$ are miller indices, $\theta$ is the angle of the corresponding peak, and $\lambda$ is the wavelength of X-ray used(1.5402 $\AA$ ).

The volume of the unit cell for the hexagonal system has been calculated by using the relation given below (6):

$\mathrm{V}=0.866^{*} \mathrm{a}^{2 *} \mathrm{c}$ 


\section{- RESULTS AND DISCUSSION}

\section{FT-IR Analysis}

FT-IR spectra were used to study the composition and structure of the $\mathrm{ZnO}$ and $\mathrm{ZnO} / \mathrm{C}$ sample calcined at different temperatures are shown in Fig. 1. For all samples, the absorption bands in the $3380-3600 \mathrm{~cm}^{-1}$ range can be assigned to the $\mathrm{O}-\mathrm{H}$ stretching vibrations, and the band about at $1550-1600 \mathrm{~cm}^{-1}$ range is attributed to $\mathrm{O}-\mathrm{H}$ bending vibration of surface-adsorbed water molecules. The presence of the sharp peak at the 400$460 \mathrm{~cm}^{-1}$ range can be attributed to the vibration of the zinc-oxygen bond. Besides, the absorption signals appeared around $702 \mathrm{~cm}^{-1}$ and were assigned for the $\mathrm{Zn}-\mathrm{O}$ stretching vibration of pure $\mathrm{ZnO}$ nanoparticles [21-22]. The presence of carbonyl groups at $1340 \mathrm{~cm}^{-1}$ came from the citric acid material. Moreover, these absorption peaks are obviously stronger for $\mathrm{ZnO} / \mathrm{C}$ composite calcined at $100{ }^{\circ} \mathrm{C}$ than the other samples. When the calcination temperature was increased for $\mathrm{ZnO} / \mathrm{C}$ composite samples to $300{ }^{\circ} \mathrm{C}$, we observed that the peaks began to decrease because the carbon mass loss changed as indicated by EDS. Table 1 shows the type of vibration IR bands for $\mathrm{ZnO} / \mathrm{C}$ composite at different calcination temperatures.

\section{X-Ray Analysis}

Fig. 2 shows the XRD diffraction patterns of the $\mathrm{ZnO}$ pure and $\mathrm{ZnO} / \mathrm{C}$ composite calcined at 100, 300, and $400{ }^{\circ} \mathrm{C}$ for $1 \mathrm{~h}$. All the main diffraction peaks were indexed in the wurtzite structure of $\mathrm{ZnO}$ with (JCPDS card No.36-1451). No obvious peaks typical of the crystalline graphitic layers of a carbonaceous material were observed because the carbon species were in the amorphous phase.

As shown in Table 2, the calculated crystallite size,

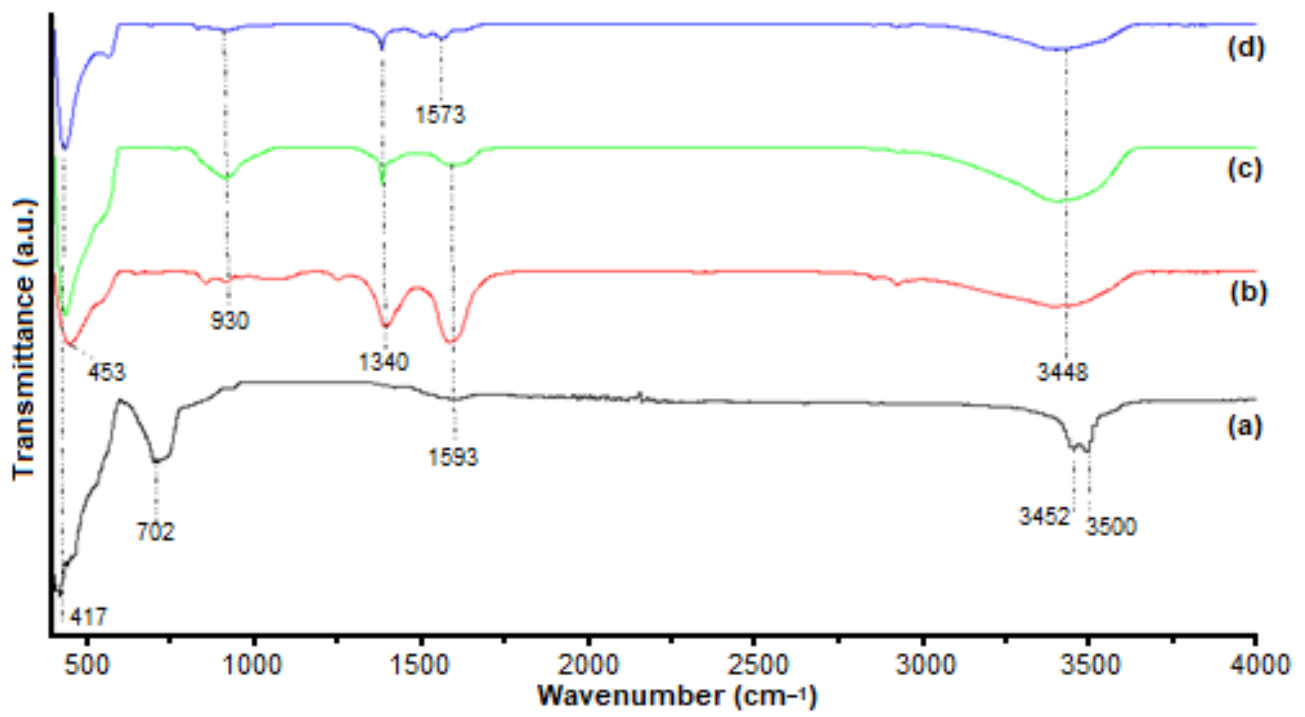

Fig 1. FTIR spectra of the synthesized $\mathrm{ZnO}$ and $\mathrm{ZnO} / \mathrm{C}$ composite calcined at different temperatures: (a) pure $\mathrm{ZnO}$ (b) $\mathrm{ZnO} / \mathrm{C}$ at $100{ }^{\circ} \mathrm{C}$, (c) $\mathrm{ZnO} / \mathrm{C}$ at $300^{\circ} \mathrm{C}$, and (d) $\mathrm{ZnO} / \mathrm{C}$ at $400{ }^{\circ} \mathrm{C}$

Table 1. The type of vibration IR bands for $\mathrm{ZnO} / \mathrm{C}$ composite at different calcination temperatures

\begin{tabular}{|c|c|c|c|c|}
\hline \multirow{2}{*}{ Type of vibration } & \multicolumn{4}{|c|}{ Wavenumber $\left(\mathrm{cm}^{-1}\right)$} \\
\hline & $\mathrm{ZnO}$ & $\mathrm{ZnO} / \mathrm{C}$ at $100^{\circ} \mathrm{C}$ & $\mathrm{ZnO} / \mathrm{C}$ at $300^{\circ} \mathrm{C}$ & $\mathrm{ZnO} / \mathrm{C}$ at $400^{\circ} \mathrm{C}$ \\
\hline \multirow{2}{*}{ assigned to $\mathrm{O}-\mathrm{H}$ stretching vibrations [23-24] } & 3500 & \multirow{2}{*}{3448} & \multirow{2}{*}{3448} & \multirow{2}{*}{3448} \\
\hline & 3452 & & & \\
\hline assigned to $\mathrm{O}-\mathrm{H}$ bending vibrations $[25]$ & 1573 & 1573 & 1573 & 1593 \\
\hline assigned to $\mathrm{C}-\mathrm{O}$ stretching vibrations [26] & - & 1340 & 1340 & 1340 \\
\hline \multirow{2}{*}{ assigned to $\mathrm{Zn}-\mathrm{O}$ bending vibration [21-22] } & 417 & \multirow{2}{*}{453} & \multirow{2}{*}{417} & \multirow{2}{*}{417} \\
\hline & 702 & & & \\
\hline
\end{tabular}




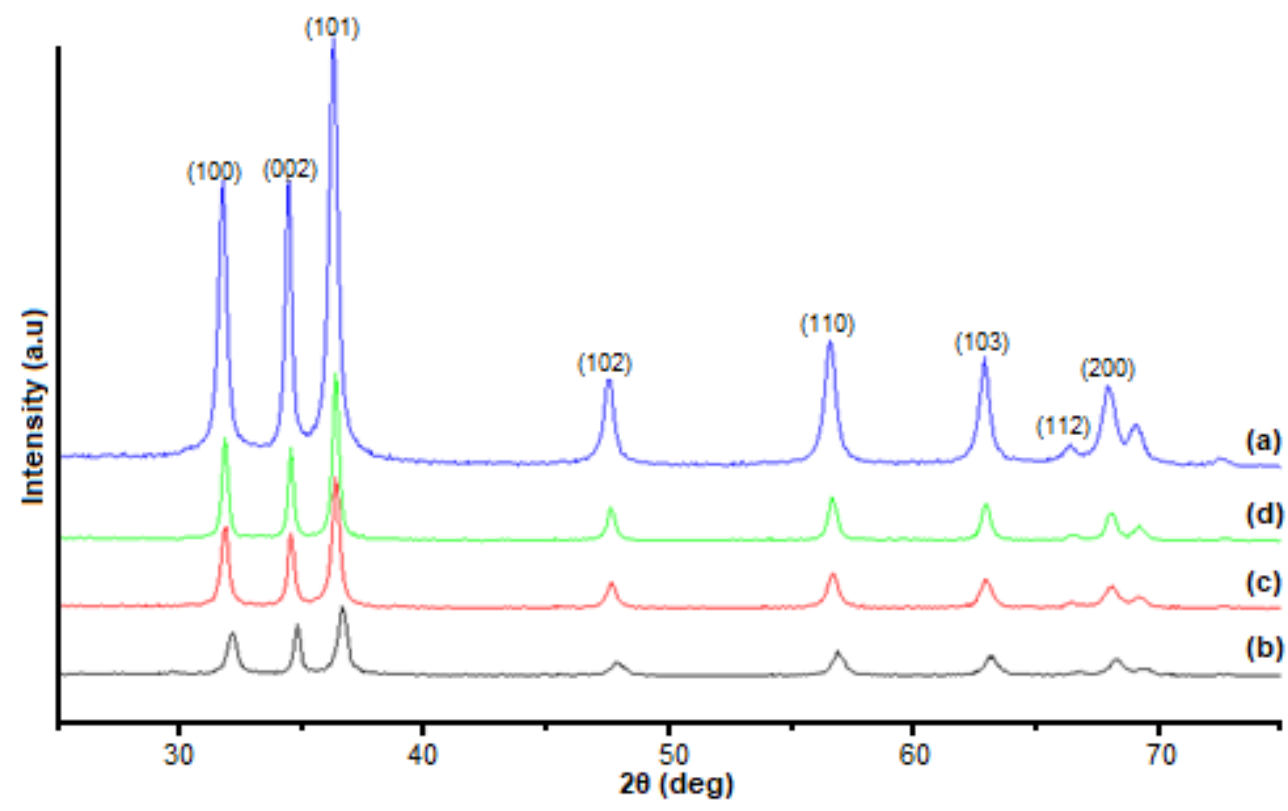

Fig 2. $\mathrm{XRD}$ spectra of the synthesized $\mathrm{ZnO}$ and $\mathrm{ZnO} / \mathrm{C}$ composite calcined at different temperatures: (a) pure $\mathrm{ZnO}$ (b) $\mathrm{ZnO} / \mathrm{C}$ at $100{ }^{\circ} \mathrm{C}$, (c) $\mathrm{ZnO} / \mathrm{C}$ at $300{ }^{\circ} \mathrm{C}$, and (d) $\mathrm{ZnO} / \mathrm{C}$ at $400{ }^{\circ} \mathrm{C}$

Table 2. Crystallite sizes, lattice volume, and lattice parameters (a and c) for $\mathrm{ZnO}$ and $\mathrm{ZnO} / \mathrm{C}$ composite calcined at different temperatures

\begin{tabular}{lcccc}
\hline & $\mathrm{D}(\mathrm{nm})$ & $\mathrm{a}(\mathrm{nm})$ & $\mathrm{c}(\mathrm{nm})$ & $\mathrm{V}\left(\mathrm{nm}^{3}\right)$ \\
\hline $\mathrm{ZnO}$ pure & 32.91 & 0.3249 & 0.4969 & 0.0454 \\
$\mathrm{ZnO} / \mathrm{C}$ at $100{ }^{\circ} \mathrm{C}$ & 28.49 & 0.3210 & 0.4919 & 0.0439 \\
$\mathrm{ZnO} / \mathrm{C}$ at $300^{\circ} \mathrm{C}$ & 31.25 & 0.3241 & 0.4956 & 0.0451 \\
$\mathrm{ZnO} / \mathrm{C}$ at $400^{\circ} \mathrm{C}$ & 31.53 & 0.3241 & 0.4957 & 0.0451 \\
\hline
\end{tabular}

lattice parameters, and unit cell volume of $\mathrm{ZnO} / \mathrm{C}$ composite are indeed smaller than those of pure $\mathrm{ZnO}$. It was observed that with the increase in calcination temperature from 100 to $400{ }^{\circ} \mathrm{C}$ with a gradual increase in crystallite size due to aggregation and also unevenly sized particles of surface atoms at higher temperatures which at higher temperatures above $100{ }^{\circ} \mathrm{C}$ reduces content carbon and improved the metal crystallinity [16].

\section{Scanning Electron Microscope (SEM)}

Fig. 3 demonstrates the correspondent morphology and calcined size at different temperature $\mathrm{ZnO} / \mathrm{C}$ composite samples, as investigated by SEM. Image of $\mathrm{ZnO} / \mathrm{C}$ composite samples calcined at $100{ }^{\circ} \mathrm{C}$ shows the sphere is of flakes (nanosheet) aggregated in the common nucleus like a grid in Fig. 3(a). The particles are about $1 \mu \mathrm{m}$ in diameter, whereas the $\mathrm{ZnO} / \mathrm{C}$ composite samples calcined at $300{ }^{\circ} \mathrm{C}$ showed the sphere consists of the spindle in the common nucleus (Fig. 3(b)). These microstructures have an average particle diameter of about 1-2 $\mu \mathrm{m}$. The samples $\mathrm{ZnO} / \mathrm{C}$ composite calcined at $400{ }^{\circ} \mathrm{C}$ showed well-defined the rods aggregated formed flowers-like with a diameter of 2-3 $\mu \mathrm{m}$ (Fig. $3(c))$. These results indicate that the attained particle size increased with increasing calcination temperature. The $\mathrm{ZnO}$ nanosheet product gradually started to crumble and overlapped with the increment of calcination temperature from $300^{\circ} \mathrm{C}$. As we know, the high surface area to volume ratio of nano-size particles possesses higher surface energy. Therefore, they tend to agglomerate due to Van der Waals's force to stabilize the surface energy. Besides that, agglomeration often occurs at high temperatures due to the sintering effect in which the particles move closer to each other during the dehydration process [27-28]. From EDS spectra, the amount of C, O, 

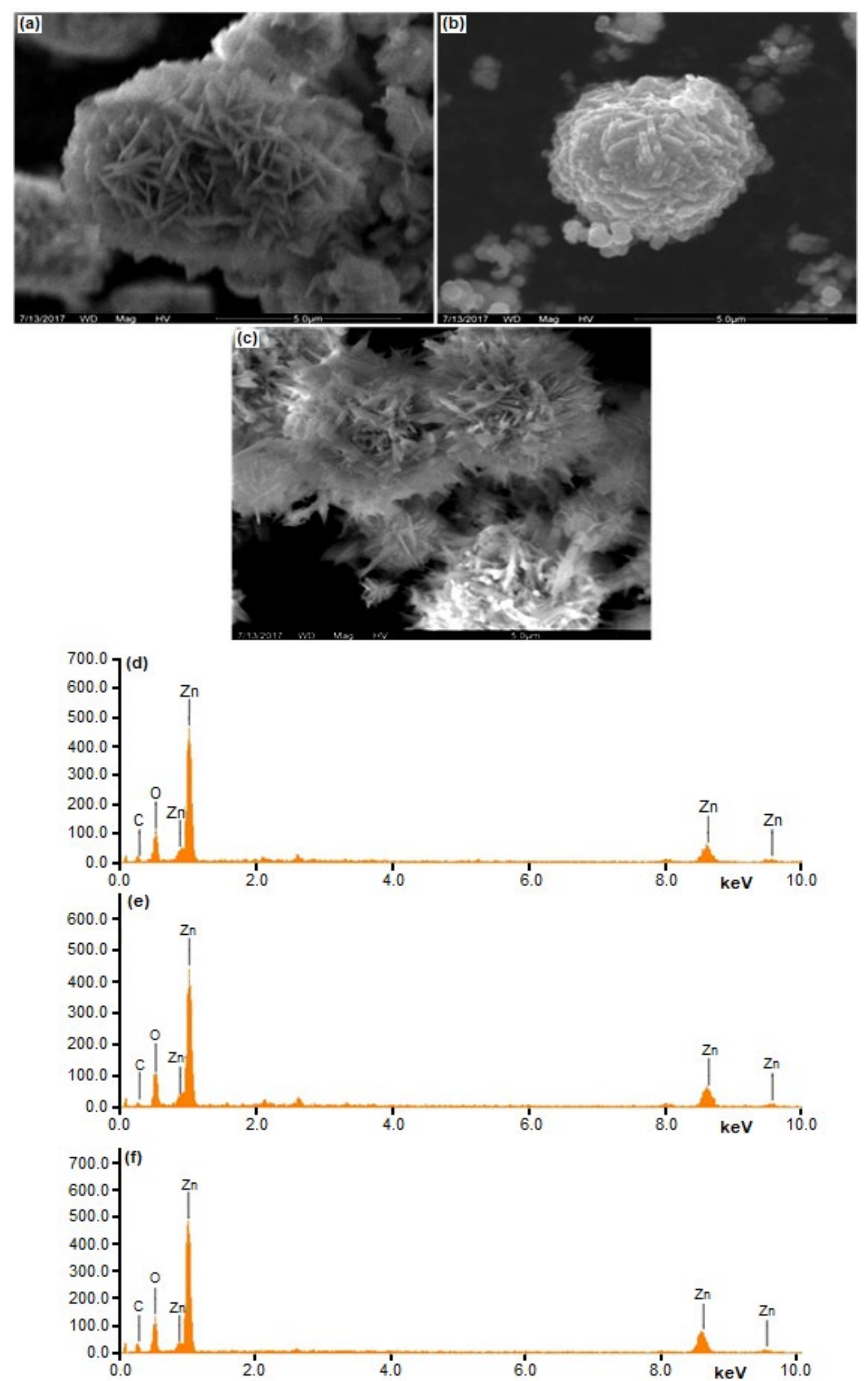

Fig 3. SEM images of the synthesized $\mathrm{ZnO} / \mathrm{C}$ composite calcined: (a) $\mathrm{ZnO} / \mathrm{C}$ at $100^{\circ} \mathrm{C}$ (b) $\mathrm{ZnO} / \mathrm{C}$ at $300{ }^{\circ} \mathrm{C}$ (c) $\mathrm{ZnO} / \mathrm{C}$ at $400{ }^{\circ} \mathrm{C}$ and EDS microanalyses: (d) $\mathrm{ZnO} / \mathrm{C}-100^{\circ} \mathrm{C}$ (e) $\mathrm{ZnO} / \mathrm{C}-300{ }^{\circ} \mathrm{C}$ (f) $\mathrm{ZnO} / \mathrm{C}-400{ }^{\circ} \mathrm{C}$ 
Table 3. The amount of $\mathrm{C}$ present in $\mathrm{ZnO}$ calcined at 100,300 , and $400{ }^{\circ} \mathrm{C}$

\begin{tabular}{cccc}
\hline Temperature of calcination $\left({ }^{\circ} \mathrm{C}\right)$ & C content $(\%)$ & O content $(\%)$ & Zn content $(\%)$ \\
\hline 100 & 12.97 & 29.57 & 57.46 \\
300 & 10.40 & 32.45 & 57.15 \\
400 & 8.30 & 32.38 & 59.32 \\
\hline
\end{tabular}

and $\mathrm{Zn}$ present in the sample was estimated as presented in Table 3, the content of carbon in the composite for the $\mathrm{ZnO} / \mathrm{C}-100{ }^{\circ} \mathrm{C}, \mathrm{ZnO} / \mathrm{C}-300{ }^{\circ} \mathrm{C}$, and $\mathrm{ZnO} / \mathrm{C}-400{ }^{\circ} \mathrm{C}$ are about $12.97 \mathrm{wt} . \%, 8.30 \mathrm{wt} . \%$, and $8.55 \mathrm{wt} . \%$, respectively. These results reveal that the carbon content of the samples decreases with increasing the temperature of calcination.

\section{Optical Properties: UV-Vis}

The Optical Properties of the $\mathrm{ZnO}$ and $\mathrm{ZnO} / \mathrm{C}$ composite calcined at different temperatures 100, 300, and $400{ }^{\circ} \mathrm{C}$ were studied by the UV-visible absorption spectra shown in Fig. 4. Fig. 4 shows display the sharp fundamental absorption in the ultraviolet region with a band gap absorption edge of 350, 354, 362, and $369 \mathrm{~nm}$ for $\mathrm{ZnO}$ and $\mathrm{ZnO} / \mathrm{C}-100{ }^{\circ} \mathrm{C}, \mathrm{ZnO} / \mathrm{C}-300{ }^{\circ} \mathrm{C}, \mathrm{ZnO} / \mathrm{C}-400{ }^{\circ} \mathrm{C}$, respectively, which can be assigned to the intrinsic bandgap absorption of $\mathrm{ZnO}$ due to the electron transitions from the valance to the conduction band.

The band gap of semiconductors can be calculated by the Kubelka-Munk method [29]. The absorption coefficient $(\alpha)$ versus photon energy $(h v)$ for the direct band gap semiconductor can be expressed as follows:

$(\alpha \mathrm{h} v)^{2}=\mathrm{B}(\mathrm{h} v-\mathrm{Eg})^{\mathrm{n}}=\mathrm{f}(\mathrm{h} v)$

where $\alpha$ is absorption coefficient, $A$ the absorption of a sample, and $t$ is the thickness of the sample, $B$ is a constant, Eg the optical band gap, h is Plank's constant, $v$ is the frequency of the incident photon. The value of $n$ $=1 / 2,3 / 2,2$, or 3 depending on the nature of the electronic transition responsible for absorption and $\mathrm{n}=$ $1 / 2$ for direct band gap semiconductor.

The value of the band gap is calculated by extrapolating the straight-line portion of the $(a h v)^{2}$ versus (hv) axis. The Plot $(\alpha h v)^{2}$ as a function of the energy $h v$ and extrapolating the linear part of the curve to the zero absorption are shown in Fig. 5.

We can see from Fig. 5 that the energy band gap for $\mathrm{ZnO}$ pure is calculated to be $3.385 \mathrm{eV}$, while the energy band gap of the $\mathrm{ZnO} / \mathrm{C}$ composite calcined at $100{ }^{\circ} \mathrm{C}$ drops down to $3.290 \mathrm{eV}$, and it can be seen that the $\mathrm{Eg}$
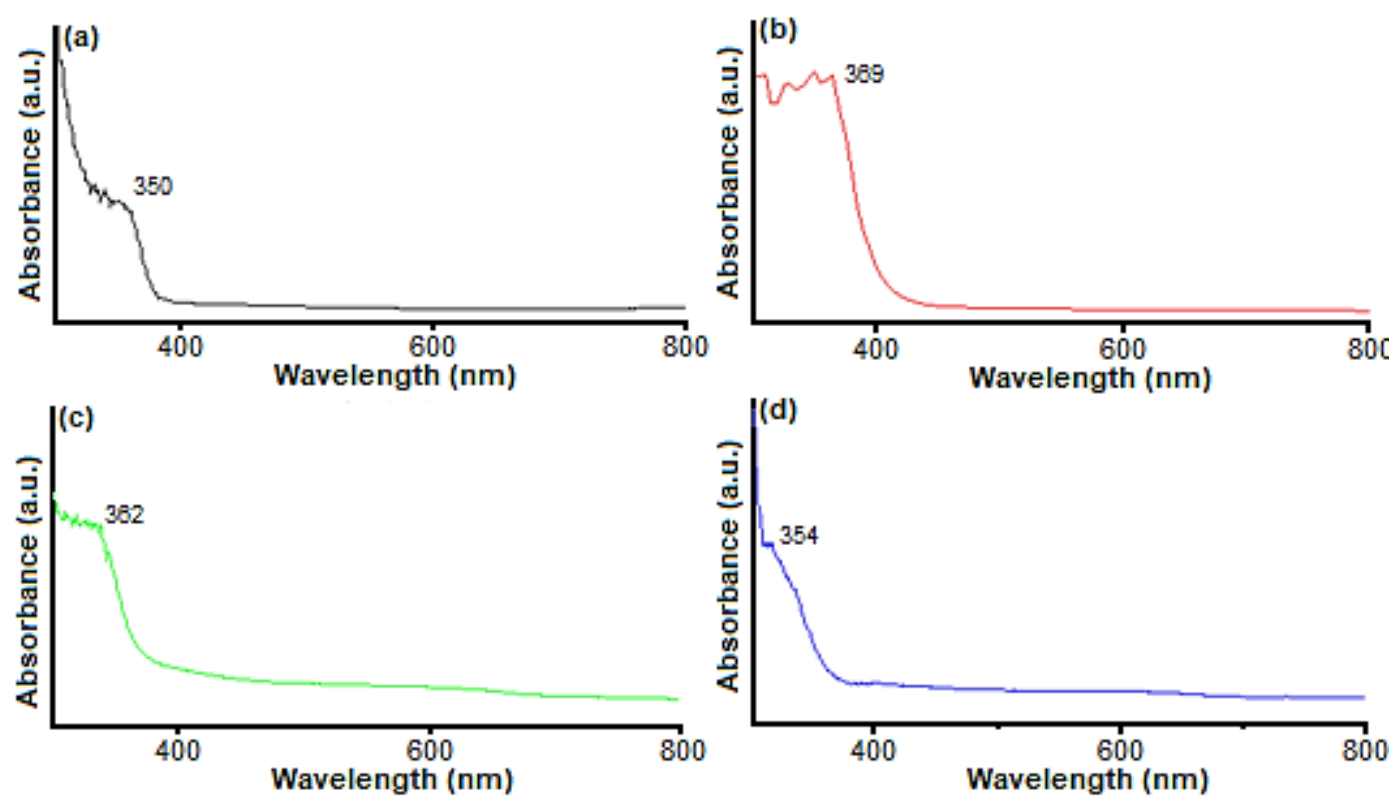

Fig 4. UV-visible absorption spectra of $\mathrm{ZnO}$ and $\mathrm{ZnO} / \mathrm{C}$ composite calcined at different temperatures: (a) pure $\mathrm{ZnO}$ (b) $\mathrm{ZnO} / \mathrm{C}$ at $100{ }^{\circ} \mathrm{C}$, (c) $\mathrm{ZnO} / \mathrm{C}$ at $300{ }^{\circ} \mathrm{C}$, and (d) $\mathrm{ZnO} / \mathrm{C}$ at $400{ }^{\circ} \mathrm{C}$ 


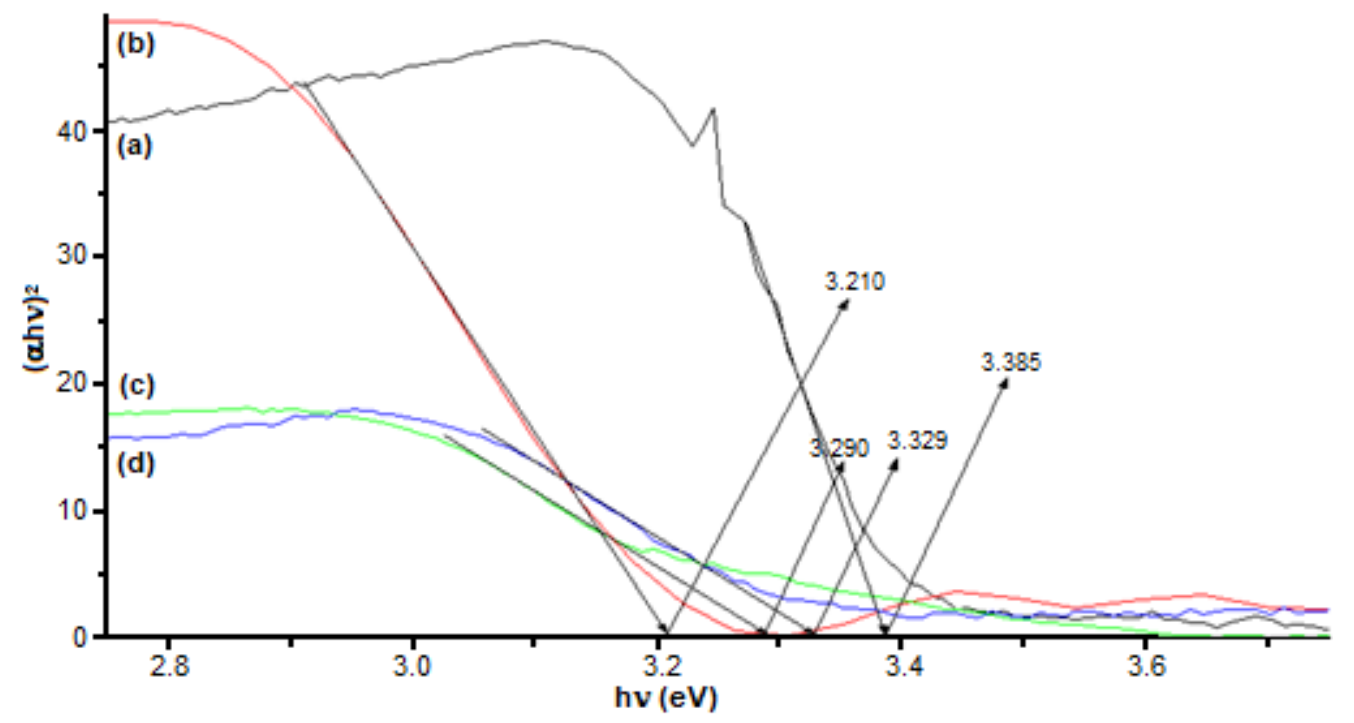

Fig 5. Plots of a function of $h v$ for the $\mathrm{ZnO}$ and $\mathrm{ZnO} / \mathrm{C}$ composite calcined at different temperatures: (a) pure $\mathrm{ZnO}$ (b) $\mathrm{ZnO} / \mathrm{C}$ at $100{ }^{\circ} \mathrm{C}$, (c) $\mathrm{ZnO} / \mathrm{C}$ at $300{ }^{\circ} \mathrm{C}$, and (d) $\mathrm{ZnO} / \mathrm{C}$ at $400{ }^{\circ} \mathrm{C}$

values of the composites increases as the calcination temperature increased. Accordingly, the existence of carbon-carrying $\mathrm{ZnO}$ can enhance the light absorption and widen the ultraviolet region range as described in $\mathrm{ZnO} / \mathrm{C}$ composites. It is clear that the increase of $\mathrm{Eg}$ is correlated along with the grain size of the material, which increases with temperature calcination (Table 4).

\section{Comparison of Size and Morphology with Other Literature}

The results of $\mathrm{ZnO} / \mathrm{C}$ composite calcined at different temperatures are compared with those reported in the literature. Table 5 summarizes the morphology, size, optical band gap, and carbon source of the $\mathrm{ZnO} / \mathrm{C}$ composite calcined at different temperatures and other publications.

\section{- CONCLUSION}

In this study, the effect of calcination temperature on the size, morphology, and optical properties of $\mathrm{ZnO} / \mathrm{C}$ composite synthesis by the colloidal method was reported. The shapes and carbon amount-of-substance fractions of the samples were characterized by SEM, EDS, and FTIR. When the calcination temperature was

Table 4. Crystallite size, band gap energy of the $\mathrm{ZnO}$ and $\mathrm{ZnO} / \mathrm{C}$ composite calcined at 100,300 , and $400{ }^{\circ} \mathrm{C}$

\begin{tabular}{lcc}
\hline Sample & Crystallite Size $(\mathrm{nm})$ & $\mathrm{Eg}(\mathrm{eV})$ \\
\hline Pure $\mathrm{ZnO}$ & 32.91 & 3.385 \\
$\mathrm{ZnO} / \mathrm{C}-100{ }^{\circ} \mathrm{C}$ & 28.49 & 3.210 \\
$\mathrm{ZnO} / \mathrm{C}-300^{\circ} \mathrm{C}$ & 31.25 & 3.290 \\
$\mathrm{ZnO} / \mathrm{C}-400{ }^{\circ} \mathrm{C}$ & 31.53 & 3.329 \\
\hline
\end{tabular}

Table 5. The morphology, size, optical band gap, and carbon source of the $\mathrm{ZnO} / \mathrm{C}$ composite and other publications

\begin{tabular}{llcclll}
\hline Method & Carbon source & $\begin{array}{c}\text { Calcined } \\
\text { temperature }\left({ }^{\circ} \mathrm{C}\right)\end{array}$ & $\begin{array}{c}\text { Size } \\
(\mathrm{nm})\end{array}$ & $\begin{array}{c}\text { Eg } \\
(\mathrm{eV})\end{array}$ & Morphology & Reference \\
\hline Colloidal method & Citric acid & 100 & 28.49 & 3.210 & - the sphere is of flakes & This work \\
& & 300 & 31.25 & 3.290 & - the sphere is of spindle & \\
& & 400 & 31.53 & 3.329 & - flowers like & \\
Sol gel method & sucrose $\left(\mathrm{C}_{12} \mathrm{H}_{22} \mathrm{O}_{11}\right)$ & 400 & 27.07 & - & Spherical particles & {$[30]$} \\
Thermal decomposition & glucose $\left(\mathrm{C}_{6} \mathrm{H}_{12} \mathrm{O}_{6}\right)$ & 350 & - & 3.221 & - & {$[8]$} \\
Combustion Synthesis & dextrose & 650 & - & - & spindle-like shapes & {$[9]$} \\
Assisted pyrolysis & Pluronic F127 & 500 & 21.8 & 2.98 & - & {$[25]$} \\
\hline
\end{tabular}


increased, the carbon amount-of-substance fraction of the product also decreased. The XRD patterns of the synthesized $\mathrm{ZnO}$ and $\mathrm{ZnO} / \mathrm{C}$ composite at different calcination temperatures revealed the presence of a single wurtzite $\mathrm{ZnO}$ phase. The particle size increased with increases in calcination temperature due to aggregation and unevenly sized particles; at higher temperatures above $100^{\circ} \mathrm{C}$, it reduced content carbon and improved the metal crystallinity. The band gap increases with increasing calcination temperature from 3.210 to $3.329 \mathrm{eV}$.

\section{- ACKNOWLEDGMENTS}

The authors would like to thank the National Center for Scientific and Technical Research (CNRST) of Morocco for putting at our disposal the technical facilities of the UATRS.

\section{- AUTHOR CONTRIBUTIONS}

SL conducted the experiment, SL and BA conducted the DFT calculations, SL, SB, and BA wrote and revised the manuscript. All authors agreed to the final version of this manuscript.

\section{- REFERENCES}

[1] Su, Y.K., Peng, S.M., Jie, L.W., Wu, C.Z., Cheng, W.B., and Liu, C.H., 2010, Ultraviolet $\mathrm{ZnO}$ nanorod photosensors, Langmuir, 26 (1), 603-606.

[2] Liu, R., Vertegel, A.A., Bohannan, E.W., Sorenson, T.A., and Switzer, J.A., 2001, Epitaxial electrodeposition of zinc oxide nanopillars on singlecrystal gold, Chem. Mater., 13 (2), 508-512.

[3] Fan, X., Zhou, Z., Wang, J., and Tian, K., 2011, Morphology and optical properties of tetrapod-like zinc oxide whiskers synthesized via equilibrium gas expanding method, Trans. Nonferrous Met. Soc. China, 21 (9), 2050-2060.

[4] Baviskar, P., Ennaoui, A., and Sankapal, B., 2014, Influence of processing parameters on chemically grown $\mathrm{ZnO}$ films with low cost Eosin-Y dye towards efficient dye sensitized solar cell, Sol. Energy, 105, 445-454.

[5] Tsuzuki, T., He, R., Dodd, A., and Saunders, M., 2019, Challenges in determining the location of dopants, to study the influence of metal doping on the photocatalytic activities of $\mathrm{ZnO}$ nanopowders, Nanomaterials, 9 (3), 481.

[6] Gertman, R., Osherov, A., Golan, Y., and VisolyFisher, I., 2014, Chemical bath deposited PbS thin films on $\mathrm{ZnO}$ nanowires for photovoltaic applications, Thin Solid Films, 550, 149-155.

[7] Lavand, A.B., and Malghe, Y.S., 2015, Visible light photocatalytic degradation of 4-chlorophenol using $\mathrm{C} / \mathrm{ZnO} / \mathrm{CdS}$ nanocomposite, J. Saudi Chem. Soc., 19 (5), 471-478.

[8] Osman, H., Su, Z., Ma, M., Liu, S., Liu, X., and Abduwayit D., 2016, Synthesis of $\mathrm{ZnO} / \mathrm{C}$ nanocomposites with enhanced visible light photocatalytic activity, Ceram. Int., 42 (8), 1023710241.

[9] Jayalakshmi, M., Palaniappa, M., and Balasubramanian, K., 2008, Single step solution combustion synthesis of $\mathrm{ZnO} /$ carbon composite and its electrochemical characterization for supercapacitor application, Int. J. Electrochem. Sci., 3, 96-103.

[10] Peña-Garcia, R., Guerra, Y., Milani, R., Oliveira, D.M., de Souza, F.R., and Padrón-Hernández, E., 2019. Influence of $\mathrm{Ni}$ and $\mathrm{Sr}$ on the structural, morphological and optical properties of $\mathrm{ZnO}$ synthesized by sol gel, Opt. Mater., 98, 109427.

[11] Bazazi, S., Arsalani, N., Khataee, A., and Tabrizi, A.G., 2018, Comparison of ball millinghydrothermal and hydrothermal methods for synthesis of $\mathrm{ZnO}$ nanostructures and evaluation of their photocatalytic performance, J. Ind. Eng. Chem., 62, 265-272.

[12] Rusli, R.A., and Hadi, N., 2017, Synthesis of carbon doped zinc oxide as visible-light driven photocatalyst, eProceed. Chem., 2 (2), 279-282.

[13] Jagtap, R.M., Kshirsagar, D.R., Khire, V.H., and Pardeshi, S.K., 2019, Facile fabrication of porous La doped $\mathrm{ZnO}$ granular nanocrystallites and their catalytic evaluation towards thermal decomposition of ammonium perchlorate, J. Solid State Chem., 276, 194-204.

[14] Ahmad, M., Ahmed, E., Zafar, F., Khalid, N.R., Niaz, N.A., Hafeez, A., Ikram, M., Khan, M.A., and 
Hong, Z., 2015, Enhanced photocatalytic activity of Ce-doped $\mathrm{ZnO}$ nanopowders synthesized by combustion method, J. Rare Earths, 33 (3), 255-262.

[15] Liu, S., Yao, K., Wang, B., and Ma, M.G., 2017, Microwave assisted hydrothermal synthesis of cellulose/ZnO composites and its thermal transformation to $\mathrm{ZnO} /$ carbon composites, Iran. Polym. J., 26 (9), 681-691.

[16] Lee, P.J., Saion, E., Al-Hada, N.M., and Soltani, N., 2015, A simple up-scalable thermal treatment method for synthesis of $\mathrm{ZnO}$ nanoparticles, Metal, 5 (4), 2383-2392.

[17] Parra, M.R., and Haque, F.Z., 2014, Aqueous chemical route synthesis and the effect of calcination temperature on the structural and optical properties of ZnO nanoparticles, J. Mater. Res. Technol., 3 (4), 363-369.

[18] Lhimr, S., Bouhlassa, S., and Ammary, B., 2019, Effect of molar ratio on structural and size of $\mathrm{ZnO} / \mathrm{C}$ nanocomposite synthesized using a colloidal method at low temperature, Indones. J. Chem., 19 (2), 422-423.

[19] Ianoş, R., Lazău, I., Păcurariu, C., and Sfirloagă, P., 2011, Aqueous combustion synthesis and characterization of $\mathrm{ZnO}$ powders, Mater. Chem. Phys., 129 (3), 881-886.

[20] Sarfraz, M., Ahmed, N., Haq, K., Shahida, S., and Khan, M.A., 2019, Structural optical and magnetic properties of transition metal doped $\mathrm{ZnO}$ magnetic nanoparticles synthesized by sol-gel autocombustion method, Mater. Sci.-Pol., 37 (2), 280288.

[21] Awad, A., Abou-Kandil, A.I., Elsabbagh, I., Elfass, M., Gaafar, M., and Mwafy, E., 2014, Polymer nanocomposites part 1: Structural characterization of zinc oxide nanoparticles synthesized via novel calcination method, J. Thermoplast. Compos. Mater., 28 (9), 1343-1358.

[22] Kayani, Z.N., Iqbal, M., Riaz, S., Zia, R., and Naseem,
S., 2015, Fabrication and properties of zinc oxide thin film prepared by sol-gel dip coating method, Mater. Sci.-Pol., 33 (3), 515-520.

[23] Puziy, A.M., Poddubnaya, O.I., Martínez-Alonso, A., Suárez-García, F., and Tascón, J.M.D., 2002, Synthetic carbons activated with phosphoric acid: I. Surface chemistry and ion binding properties, Carbon, 40 (9), 1493-1505.

[24] Hasanpour, A., Niyaifar, M., Asan, M., and Amighian, J., 2013, Synthesis and characterization of $\mathrm{Fe}$ and $\mathrm{ZnO}$ nanocomposites by the sol-gel method, J. Magn. Magn. Mater., 334, 41-44.

[25] Lanfredi, S., Silveira, G.S., Potensa, B.S., and Nobre, M.A.L, 2016, $\mathrm{ZnO} / \mathrm{Zn}$ /amorphous carbon matrix nanostructured composite powder: A new photocatalyst for dye, MRS Adv., 1 (19), 1327-1332.

[26] Lanfredi, S., Nobre, M.A.L., Moraes, P.G.P., and Matos, J., 2014, Photodegradation of phenol red on a Ni-doped niobate/carbon composite, Ceram. Int., 40 (7), 9525-9534.

[27] Al-Hada, N.M., Saion, E., Shaari, A.H., Kamarudin, M.A., and Gene, S.A., 2014, The influence of calcination temperature on the formation of zinc oxide nanoparticles by thermal-treatment, Appl. Mech. Mater., 446-447, 181-184.

[28] Al-Hada, N.M., Saion, E., Shaari, A.H., Kamarudin, M.A., Flaifel, M.H., Ahmad, S., and Gene, S., 2014, A facile thermal-treatment route to synthesize $\mathrm{ZnO}$ nanosheets and effect of calcination temperature, PLoS One, 9 (8), e103134.

[29] Ali, A.A., El Fadaly, E., and Ahmed, I.S., 2018, Nearinfrared reflecting blue inorganic nano-pigment base on cobalt aluminate spinel via combustion synthesis method, Dyes Pigm., 158, 451-462.

[30] Sasirekha, C., Arumugam, S., and Muralidharan, G., 2018, Green synthesis of $\mathrm{ZnO} /$ Carbon $(\mathrm{ZnO} / \mathrm{C}$ ) as an electrode material for symmetric supercapacitor devices, Appl. Surf. Sci., 499, 521-527. 